\title{
Adjusting NRCS Curve Number for Rainfall Durations Less Than 24 Hours
}

\author{
Michael E. Meadows
}

AUTHOR: Associate Professor, Department of Civil \& Environmental Engineering, University of South Carolina, Columbia, SC 29208, USA.

\begin{abstract}
The primary use of the Natural Resources Conservation Service (NRCS) curve number $(\mathrm{CN})$ is to compute total storm runoff based on total rainfall. The method was originally created to determine the mean daily depth of runoff during flood producing events on small agricultural watersheds. $\mathrm{CN}$ values were determined using daily rainfall and runoff data. Practically, it did not rain for 24 hours during many, perhaps most, of the events, but since the data were recorded as daily rainfall, 24 hours became the implicit duration for values input to the curve number runoff model. NRCS references do not specifically state the $\mathrm{CN}$ applies only to the 24-hour storm. Even so, it may be inferred from what is published that the standard $\mathrm{CN}$ applies to the 24 hour duration storm.

Many methods and computer models used for the analysis and design of stormwater management systems incorporate the NRCS CN method. Because some designs and performance evaluations are based on rainfalls with durations less than 24 hours, there is the need for a method to modify $\mathrm{CN}$ values for shorter duration events. It goes against basic hydrologic principles if the same $\mathrm{CN}$ is used for storms of all durations. Not yet formally published, the NRCS recently developed a procedure to modify $\mathrm{CN}$ values for rainfall durations less than 24 hours. With encouragement from the NRCS, introducing that method to the engineering community is the goal for this paper.

The impact of adjusted $\mathrm{CN}$ values was demonstrated by calculations comparing runoff depths computed with standard and duration modified $\mathrm{CN}$ values for rainfalls of $1,2,3,6,12$, and 24 hour duration. The standard $\mathrm{CN}$ significantly under-predicted runoff depths compared to the duration modified $\mathrm{CN}$ values. The differences increased with shorter duration storms.

The impact of adjusted $\mathrm{CN}$ values also was demonstrated during a forensic assessment of the performance of a stormwater detention pond in a residential subdivision. The pond was designed compliant with regulations to limit the post-development peak discharge rate at or below the pre-development peak runoff rate for 2- and 10-year frequency 24-hour design storm events. Even though the pond design met regulatory standards for 24-hour design storms, downstream flooding and sediment problems
\end{abstract}

frequently occurred during short duration events. As part of the forensic study, runoff hydrographs were simulated for pre-development, construction phase, and post-development land use conditions for rainfalls of 1, 2, 3, 6, 12, and 24 hour duration. The simulation results for post development conditions showed successful pond performance for the 24hour rainfall. However, the peak outflow rates for storms with durations less than 24-hours were greater than the 24hour pre-development peak runoff rate.

The simulation results emphasize pond design calculations and decisions should include pond performance for events with duration less than 24 hours and should use duration modified $\mathrm{CN}$ values. It is recommended controlling regulations specify design events such as the 2- and 10-year 24-hour rainfalls, but include a mandatory check of other events, such as the 1, 2, 3, 6 and 12 hour events. Prudent and ethical practice suggests pond design be upgraded for the critical rainfall event.

\section{INTRODUCTION}

The NRCS-CN rainfall-runoff model was originally created for the purpose of determining the mean daily depth of runoff experienced during flood producing events on small agricultural watersheds (Rallison and Miller 1982). $\mathrm{CN}$ values for particular combinations of soil and cover characteristics were developed by plotting largest annual storm runoff and associated rainfall for a watershed having one soil and one cover. Developed in the 1950s for internal use, the curve number method for estimating direct runoff from rainstorms is now widely used for applications such as engineering design, forensic analysis, and environmental impact studies. Background for this method is found in the NRCS National Engineering Handbook, Section 4, "Hydrology", or "NEH-4" (SCS, 1985). In the general runoff equation $\mathrm{Q}_{\mathrm{CN}}$ (author's terminology; NRCS uses $\mathrm{Q}$ ) is the runoff volume in watershed inches, $\mathrm{P}$ is the cumulative rainfall depth in inches, $\mathrm{CN}$ is curve number, $\mathrm{S}$ is watershed retention, and $I_{a}$ is initial abstractions which include rainfall lost to interception by vegetation, rooftops, etc., depression storage, and initial high rate infiltration. 
During development of this method, $\mathrm{CN}$ values were determined using daily, i.e., 24 hour, rainfall and runoff data, which is the implicit duration for values input to the curve number runoff model. Duration is not factored into the calculation. NRCS references do not specifically state the $\mathrm{CN}$ applies only to the 24-hour storm. Even so, it may be inferred from what is published that the standard $\mathrm{CN}$ applies to the 24 hour duration storm. As explained by William Merkel, Hydraulic Engineer, USDA-Natural Resources Conservation Service, Beltsville, MD, "You cannot use the standard curve number for any duration other than 24 hours. If you do, you need to increase it for durations less than 24 hours and decrease $\mathrm{CN}$ for durations longer than 24 hours." (W. Merkel, pers. comm., 2013).

In many locations, the design of stormwater management systems, such as detention ponds, must satisfy the regulation to limit the post-development peak discharge rate at or below the pre-development peak runoff rate for the 2 and 10 year frequency 24 hour duration storm events. During recent years, some locations added shorter duration events for stormwater pond design, such as 6 and 12 hours. Stormwater quality control using Best Management Practices (BMPs) also involves design rainfall events with durations less than 24 hours.

Because most models used to design stormwater ponds and BMPs incorporate the NRCS CN method and since some designs now are based on rainfalls with durations less than 24 hours, there is need for a way to modify $\mathrm{CN}$ values for shorter events. Not yet formally published, the NRCS recently developed a standard procedure for modifying $\mathrm{CN}$ values for rainfall durations less than 24 hours. With encouragement from the NRCS, introducing that method to the engineering community is the goal for this paper.

\section{RELATED WORK}

The NRCS rainfall-runoff model has limited use in the analysis of small volume, short duration storms that are becoming increasingly important because of their association with water quality issues such as first-flush events and, subsequently, the design of BMPs. Using the NRCS CN runoff equation often yields very low to zero estimates of runoff depths for small rainfall depths. Interest has developed to increase $\mathrm{CN}$ values such that the $\mathrm{CN}$ runoff equation yields runoff depths that are more reasonable than those generated using standard values obtained from the $\mathrm{CN}$ table. Work is ongoing at the University of Maryland (McCuen, 2015) to incorporate storm duration into the NRCS rainfall-runoff model to make it suitable for application to short-duration events. Storm duration is one factor that is not directly considered in the standard NRCS model. However, duration has been reported as a factor in $\mathrm{CN}$ hydrology. Woodward (1973) reported the curve number decreases with increasing storm duration. Objectives of the University of Maryland work are to revise the maximum potential retention to incorporate storm duration and evaluate the accuracy of the revised method using short duration events (McCuen, 2016).

\section{PROJECT DESCRIPTION}

A basic hydrologic principle underlying the NRCS $\mathrm{CN}$ adjustment procedure is that after initial abstractions have been satisfied, water infiltrates into the soil at nearly a steady rate. For a given rainfall depth, if the event duration is extended over a longer period of time, more rainfall will infiltrate. If the storm occurs over a shorter duration, less rainfall will infiltrate and more will go to runoff.

This concept was explained as follows (W. Merkel, pers. comm., 2013). At a watershed with $\mathrm{CN}$ value of 80 , for 4 inches of rainfall, the runoff is 2.04 inches. For rainfall duration of 1 hour, the runoff would be 2.04 inches and for 24 hours rainfall duration, the runoff also would be 2.04 inches. If you use the standard curve number for a 60 minute storm, it assumes that you have 24 hours of infiltration in just 60 minutes. This concept is technically invalid.

The $\mathrm{CN}$ adjustment procedure follows steps shown in Table 1. The order of calculations is founded on the basic hydrologic principle that after initial abstractions have been satisfied, water infiltrates into the soil at nearly a steady rate. For a given rainfall depth, if the event duration is extended over a longer period of time, more rainfall will infiltrate. If the storm occurs over a shorter duration, less rainfall will infiltrate and more will go to runoff.

\section{METHOD}

Table 1 shows steps and calculations to compute the adjusted $\mathrm{CN}$ value for storm duration of 1 hour. The same table is used for other duration storms using the appropriate duration data. For this example, the standard $\mathrm{CN}$ is 74 , which corresponds to pre-development land use conditions in Table 2. Standard CN is CN-II for average conditions and refers to the $\mathrm{CN}$ obtained from the published NRCS CN table based on land use and soils information. This value is labeled 24-Hour CN. The objective of the calculations outlined in Table 1 is to compute the 1 -Hour $\mathrm{CN}$, which is greater than the standard 24-hour CN.

\section{RESULTS}

The impact of adjusted $\mathrm{CN}$ values was demonstrated by calculations comparing runoff depths computed with standard and duration modified $\mathrm{CN}$ values for rainfalls of 1, 2, 3, 6, 12 , and 24 hour durations. Runoff depths were computed for pre-development (Table 3) and post-development (Table 4) land uses. In both cases, the standard $\mathrm{CN}$ significantly underpredicted runoff depths calculated with duration modified $\mathrm{CN}$ values. The differences were increasingly greater for shorter duration events.

To further study the impact of adjusting $\mathrm{CN}$ values, revised values, shown in Table 2, were used in an assessment of the performance of a stormwater detention pond in a recently built residential subdivision. The pond was designed to limit 
Table 1. CN modification worksheet.

\begin{tabular}{|c|c|}
\hline & 24 Hours \\
\hline 24-hr CN = & 74 \\
\hline $24-\mathrm{hr} \mathrm{S}=$ & 3.51 \\
\hline 24-hr Ia $=$ & 0.70 \\
\hline $\mathrm{D}-\mathrm{hr}=$ & 1 Hour \\
\hline $\mathrm{D}-\mathrm{hr} \mathrm{P}=$ & 2.50 \\
\hline $\begin{array}{l}\text { Assume D-hr P occurs in } 24 \text { hours and compute } \\
24-\mathrm{hr} \mathrm{Q}_{\mathrm{CN}}=\end{array}$ & 0.61 \\
\hline $\begin{array}{r}\text { 24-hr Infiltration = 24-hr F }=\text { D-hr P minus 24-hr } \\
\text { Ia minus } 24-\mathrm{hr} \mathrm{Q}_{\mathrm{CN}}=\end{array}$ & 1.19 \\
\hline 24-hr Infiltration Rate $=24-\mathrm{hr} F$ divided by $24=$ & 0.05 \\
\hline $\begin{array}{r}\text { 24-hr Infiltration Rate multiplied by D hours }= \\
\text { D-hr Infiltration }=\end{array}$ & 0.05 \\
\hline D-hr Infiltration plus Ia = & 0.75 \\
\hline $\begin{array}{r}\text { D-hr P minus D-hr Infiltration plus Ia }=\text { D-hr } \\
\text { Runoff }=\end{array}$ & 1.75 \\
\hline $\begin{array}{l}\text { Use D-hr P and D-hr Runoff to compute D-hr } \\
\qquad \mathrm{CN}=\end{array}$ & 92.6 \\
\hline
\end{tabular}

Table 2. 10-year Design Rainfall and Modified CN Values.

\begin{tabular}{|c|c|c|c|c|}
\hline \multicolumn{2}{|c|}{ Design Rainfall Data } & \multicolumn{3}{|c|}{$\begin{array}{c}\text { CN Adjusted for Rainfall Duration } \\
\qquad<24-\mathrm{hr}\end{array}$} \\
\hline D hrs & D-hr P (in) & Pre-dev & Construction & Post \\
\hline 1 & 2.50 & 92.6 & 97.8 & 95.6 \\
\hline 2 & 2.92 & 92.2 & 97.5 & 95.1 \\
\hline 3 & 3.11 & 91.6 & 97.2 & 94.6 \\
\hline 6 & 3.70 & 89.5 & 96.2 & 93.0 \\
\hline 12 & 4.38 & 84.8 & 94.2 & 89.6 \\
\hline 24 & 5.25 & 74.0 & 90.0 & 82.0 \\
\hline Location & Blythewood & & & \\
\hline RP (yrs) & 10 & & & \\
\hline
\end{tabular}

the peak outflow for a 10-year 24-hour rainfall at or below the pre-development peak runoff. As part of the assessment of the impact of modified $\mathrm{CN}$ values, runoff hydrographs were simulated for pre-development, construction phase, and postdevelopment land use conditions for rainfalls of 1, 2, 3, 6, 12, and 24 hour durations.

The results for the pond design based on postdevelopment outflow peak less than or equal to predevelopment runoff peak (Table 5) yielded outflow peaks for all duration events less than the corresponding predevelopment runoff peak rates. All shorter duration events had a peak outflow that exceeded the pre-development peak runoff for the 24-hour rainfall by as much as 10 to
Table 3. Comparison of pre-development runoff depths calculated with duration modified curve numbers and standard 24-hr curve number.

\begin{tabular}{|c|c|c|c|c|c|c|}
\cline { 3 - 7 } \multicolumn{2}{c|}{} & \multicolumn{2}{c|}{$\begin{array}{c}\text { Duration } \\
\text { Modified }\end{array}$} & \multicolumn{3}{c|}{$\begin{array}{c}\text { Standard, Not Duration } \\
\text { Modified }\end{array}$} \\
\hline $\begin{array}{c}\text { D } \\
\text { hrs }\end{array}$ & $\begin{array}{c}\text { D-hr } \\
\text { P }\end{array}$ & $\begin{array}{c}\text { D-hr } \\
\text { CN }\end{array}$ & $\begin{array}{c}\text { D-hr } \\
Q_{C N}\end{array}$ & CN & Std Q & $\begin{array}{c}\text { Std } Q_{\mathrm{CN}} \\
\text { Error }\end{array}$ \\
\hline 1 & 2.50 & 92.6 & 1.75 & 74.0 & 0.61 & $-65.1 \%$ \\
\hline 2 & 2.92 & 92.2 & 2.10 & 74.0 & 0.86 & $-59.2 \%$ \\
\hline 3 & 3.11 & 91.6 & 2.23 & 74.0 & 0.98 & $-56.1 \%$ \\
\hline 6 & 3.70 & 89.5 & 2.59 & 74.0 & 1.38 & $-46.7 \%$ \\
\hline 12 & 4.38 & 84.8 & 2.78 & 74.0 & 1.88 & $-32.4 \%$ \\
\hline 24 & 5.25 & 74.0 & 2.57 & 74.0 & 2.57 & $0.0 \%$ \\
\hline
\end{tabular}

Table 4. Comparison of post-development runoff depths calculated with duration modified curve numbers and standard 24hr curve number.

\begin{tabular}{|c|c|c|c|c|c|c|}
\hline & & \multicolumn{2}{|c|}{$\begin{array}{c}\text { Duration } \\
\text { Modified }\end{array}$} & \multicolumn{4}{c|}{$\begin{array}{c}\text { Standard, } \\
\text { Not Duration Modified }\end{array}$} \\
\hline $\begin{array}{c}\text { D } \\
\text { hrs }\end{array}$ & $\begin{array}{c}\text { D-hr } \\
\text { P }\end{array}$ & $\begin{array}{c}\text { D-hr } \\
\text { CN }\end{array}$ & $\begin{array}{c}\text { D-hr } \\
Q_{\mathrm{CN}}\end{array}$ & CN & Std $Q_{\mathrm{CN}}$ & $\begin{array}{c}\text { Std } \mathrm{Q}_{\mathrm{CN}} \\
\text { Error }\end{array}$ \\
\hline 1 & 2.50 & 95.60 & 2.02 & 82.0 & 1.00 & $-50.6 \%$ \\
\hline 2 & 2.92 & 95.10 & 2.38 & 82.0 & 1.32 & $-44.7 \%$ \\
\hline 3 & 3.11 & 94.60 & 2.52 & 82.0 & 1.47 & $-41.7 \%$ \\
\hline 6 & 3.70 & 93.00 & 2.93 & 82.0 & 1.95 & $-33.4 \%$ \\
\hline 12 & 4.38 & 89.60 & 3.24 & 82.0 & 2.53 & $-21.9 \%$ \\
\hline 24 & 5.25 & 82.00 & 3.30 & 82.0 & 3.30 & $0.0 \%$ \\
\hline
\end{tabular}

$33 \%$. Stated differently, the pond outflow peak rates for the 1, 2, 3, 6 and 12 hour events were all greater than the pre-development peak runoff rate for the 24-hour rainfall event. Not all applications will have similar results, but these results underscore the importance of evaluating pond performance for non-24 hour events.

The construction phase peak outflow rates (Table 6) were 8.7 to $54 \%$ greater than the pre-development peaks, and all shorter duration events exceeded the pre-development 24 hour peak runoff rate by as much as 40 to $67 \%$, which helps to explain why there was recurring flooding and sediment problems during shorter duration storm events. 
Table 5. Post development pond outflow peaks.

\begin{tabular}{|c|c|c|c|c|c|c|}
\hline \multirow{2}{*}{$\begin{array}{c}\text { Storm } \\
\text { Duration (hrs) }\end{array}$} & $\begin{array}{c}\text { Pre-development } \\
\text { Peak Runoff } \begin{array}{c}\text { Q } \\
\text { (cfs) }\end{array}\end{array}$ & \multicolumn{3}{|c|}{$\begin{array}{c}\text { Does the Pond Outflow Peak indicate an increase or decrease in watershed } \\
\text { peak flowrate relative to the Pre-development Peak Rate? }\end{array}$} \\
\cline { 3 - 7 } & & $\begin{array}{c}|c| \\
\text { Pond } \\
\text { Outflow } \\
\text { Peak (cfs) }\end{array}$ & \% Change & $\begin{array}{c}\text { Increase or } \\
\text { Decrease? }\end{array}$ & $\begin{array}{c}\text { Is Pond Qp > 24- } \\
\text { hr Predev Peak? }\end{array}$ & $\begin{array}{c}\text { How much } \\
\text { greater? }\end{array}$ \\
\hline 1 & 15.48 & 13.34 & $-13.9 \%$ & Decrease & Yes & $10.9 \%$ \\
\hline 2 & 16.59 & 14.82 & $-10.7 \%$ & Decrease & Yes & $23.2 \%$ \\
\hline 3 & 16.35 & 14.66 & $-10.3 \%$ & Decrease & Yes & $21.9 \%$ \\
\hline 6 & 17.02 & 16.06 & $-5.6 \%$ & Decrease & Yes & $33.5 \%$ \\
\hline 12 & 15.44 & 14.86 & $-3.7 \%$ & Decrease & Yes & $23.5 \%$ \\
\hline 24 & 12.03 & 12.03 & $0.0 \%$ & Decrease & & \\
\hline
\end{tabular}

Table 6. Construction phase pond outflow peaks.

\begin{tabular}{|c|c|c|c|c|c|c|}
\hline \multirow{3}{*}{$\begin{array}{l}\text { Storm Duration } \\
\text { (hrs) }\end{array}$} & \multirow{3}{*}{$\begin{array}{l}\text { Pre-development } \\
\text { Peak Runoff } Q_{p} \\
\text { (cfs) }\end{array}$} & \multicolumn{5}{|c|}{$\begin{array}{c}\text { Does the Pond Outflow Peak indicate an increase or decrease in watershed } \\
\text { peak flowrate relative to the Pre-development Peak Rate? }\end{array}$} \\
\hline & & \multicolumn{5}{|c|}{ Construction Phase } \\
\hline & & $\begin{array}{c}\text { Pond } \\
\text { Outflow Peak } \\
\text { (cfs) }\end{array}$ & $\begin{array}{c}\% \\
\text { change }\end{array}$ & $\begin{array}{l}\text { Increase or } \\
\text { Decrease? }\end{array}$ & $\begin{array}{l}\text { Is Pond Qp > 24-hr } \\
\text { Predev Peak? }\end{array}$ & $\begin{array}{l}\text { How much } \\
\text { greater? }\end{array}$ \\
\hline 1 & 15.48 & 16.83 & $8.7 \%$ & Increase & Yes & $39.9 \%$ \\
\hline 2 & 16.59 & 18.54 & $11.8 \%$ & Increase & Yes & $54.1 \%$ \\
\hline 3 & 16.35 & 18.38 & $12.4 \%$ & Increase & Yes & $52.8 \%$ \\
\hline 6 & 17.02 & 20.16 & $18.4 \%$ & Increase & Yes & $67.5 \%$ \\
\hline 12 & 15.44 & 19.67 & $27.4 \%$ & Increase & Yes & $63.5 \%$ \\
\hline 24 & 12.03 & 18.54 & $54.1 \%$ & Increase & Yes & $54.1 \%$ \\
\hline
\end{tabular}

Collectively, the results in Tables 2 through 6 emphasize pond design calculations and decisions should include pond performance for events with duration less than 24 hours and should use modified $\mathrm{CN}$ values. Controlling regulations should specify design events such as the 2- and 10-year 24-hour rainfalls, but include a mandatory check of other events, such as the 1, 2, 3, 6 and 12 hour events, and other return periods.

\section{DISCUSSION}

An obvious implication of these results is that traditional design guidelines based on 24-hour rainfall events, unbeknown before the adjusted $\mathrm{CN}$ concept was available, were wrongly founded and not supported by science. Designs based on those regulations are wrong, incomplete, and fail to perform to the standard which designers, regulators, and the general public expect. Those regulations should be modified. But what if we do not modify the standards, what should designers do? They should accomplish a design that minimally meets the regulations and then check system performance using the adjusted $\mathrm{CN}$ values. If the system performance fails, modify the design. An appropriate design is one that will uphold public welfare, health, and safety, and will not damage on-site, adjacent, and off-site property, as a minimum. Development property owners and designers may argue this approach will increase the cost. Wouldn't it be better to pay more upfront for a safe design than incur sizable costs later mandated by the legal system to pay for damages resulting from an unsafe system that only satisfies the minimum standard? 


\section{LITERATURE CITED}

Fennessey, L.A.J. and Hawkins, R.H., 2001. The NRCS Curve Number, a New Look at an Old Tool, Proceedings of the 2001 Pennsylvania Stormwater Management Symposium Re-thinking Comprehensive Stormwater ManagementIntegrating Quality, Volume and Peak Controls.

Hawkins, R.H., A.T. Hjelmfelt, A.T. and Zevenbergen, A.W. 1985. Runoff Probability, Storm Depth, and Curve Numbers. Journal of Irrigation and Drainage Engineering, ASCE 111(4):330-340.

Hawkins, R.H., Ward, T.J., Woodward, D.E., and Van Mullem, J.A. 2009. Curve Number Hydrology: State of the Practice. ASCE Press. Reston, VA.

McCuen, R.H. 2016. Hydrologic Analysis and Design 4th ed. Pearson/Prentice-Hall, Upper Saddle River, NJ.

Rallison, R.E. and Miller, N. 1982. Past, Present, and Future of the SCS Runoff Procedure. Presented at the Intern. Symp. on Rainfall-Runoff Modeling. Miss. St. Univ. Water Resources Publication. 353-364.

United States Department of Agriculture, Soil Conservation Service. 1986. Urban Hydrology for Small Watersheds. Technical Release No. 55. Second Edition. Washington, D.C.

U.S. Department of Agriculture, Soil Conservation Service. 1993. National Engineering Handbook. Section 4, Hydrology. Washington, DC.

Woodward, D.E. 1973. Runoff Curve Numbers for Semiarid Range and Forest Conditions. Presented at the ASAE 1973 Annual Meeting (17-209), Lexington, KY.

Woodward, D.E, Hawkins, R.H., Hjelmfelt, A.T.J., Van Mullem, J. and Quan. Q.D. 2002. Curve Number Method: Origins, Applications and Limitations 2002 U.S. Geological Survey Advisory Committee on Water Information-Second Federal Interagency Hydrologic Modeling Conf. Las Vegas, NV. 